\title{
Teaching Writing without academic Writing: Transitioning from Aristotle to the Twitter World
}

\author{
Bruce M. Gatenby \\ American University of Sharjah \\ UAE
}

\begin{abstract}
Technology has made traditional models of teaching writing obsolete. The thesis-based five paragraph essay and the research-based essay are no longer viable, both because of changes in the nature of information consumption and the ability of students to purchase custom-written essays online that are virtually plagiarism-detection proof. The traditional model of liberal education served the needs of a leisure-based class, which the information revolution has also rendered obsolete. Writing programs should be focused on the types of writing that students will actually do once they leave the University for the Work World, writing that focuses on technical and workrelated skills they will actually use on the job. The fundamental nature of writing has changed from an Aristotelian model to one of Facebook, Twitter, IMs and emails. The ability to convey information in short, direct bursts of writing is now the standard model of communication, not the ability to write long, complex sentences in fully developed paragraphs. Until writing programs accept and focus on this fundamental change in the worlds of information and education, they will continue their downward slide into educational irrelevance.
\end{abstract}

Keywords: Rhetoric, argument, composition, research, technology

Teaching Writing without Academic Writing: Transitioning from Aristotle to the Twitter World

Technology has made traditional models of teaching writing obsolete. The thesis-based five paragraph essay and the research-based essay are no longer viable, both because of changes in the nature of information consumption and the ability of students to purchase custom-written essays online that are virtually plagiarism-detection proof. The traditional Aristotelian model of rhetoric no longer meets the needs of technology-based writing:(xx)The proofs common to all three kinds of rhetoric are: example and enthymeme (maxims being included under the latter). Examples are either (1) statements of things that have actually happened; or (2) invented by the speaker, consisting of (a) comparisons, (6) fables.

(xxi) Maxims are general statements relating to human actions, and teach what should be chosen or avoided. Maxims are the conclusions and premises of enthymemes, when the form of the syllogism is absent; when the why and the wherefore are added, the result is a true enthymeme. The four kinds of maxims. Directions for their use.

(xxii) Enthymemes must be neither too far-fetched nor too general; they must not be drawn from all opinions, but from such as are defined (e.g. by the judges): and conclusions must not be drawn only from necessary, but also from probable, premises. The speaker must also be acquainted with the special elements of the case. Enthymemes are: (1) demonstrative, which draw a conclusion from acknowledged premises; (2) refutative, which draw a conclusion which is not admitted by the opponent (Freese)

The fundamental nature of writing has changed from an Aristotelian model to one of Facebook, Twitter, IMs and emails. The ability to convey information in short, direct bursts of writing is now the standard model of communication, not the ability to write long, complex sentences in fully developed paragraphs. The traditional model of liberal education served the needs of a leisure-based class, which the information revolution has also rendered obsolete. In Skin in the Game(2018), Nassim Nicholas Taleb points out, "In academia there is no difference between academia and the real world; in the real world, there is" (3). Writing programs should be focused on the types of writing that students will actually do once they leave the University for the Work World, writing that focuses on technical and work-related skills they will actually use on the job. Until writing programs accept and focus on this fundamental change in the worlds of information and education, they will continue their downward slide into educational irrelevance. 
My first semester in graduate school the chair of the Rhetoric and Composition program, which employed over 160 TA's teaching two freshman composition classes per semester for near-starvation wages, told us that the teaching of writing was the most important job on campus. I remember thinking, if it's so important, why are we teaching it?

A quarter of a century after this epiphany much has changed. The humanities have become largely irrelevant in the struggle for the soul of the university system and its increasing role as a certificate mill for employment, legions of underpaid adjuncts now stand shoulder to shoulder on the general education ramparts with underpaid TA's responsible for teaching the "most important job on campus," and the Internet has made both traditional research skills and, I would argue, the necessity for students to write academic essays obsolete. According to a recent study by the citation project, "An analysis of research papers written in first-year composition courses at 15 colleges reveals that many students simply copy chunks of text from the sources they cite without truly grasping the underlying argument, quality or context." Students can also buy any paper they need from dozens of online essay mills, papers that plagiarism software tools such as Safe Assign cannot catch and teachers are wasting their time evaluating as indicative of a student's supposed writing ability and critical thinking skills. While educators bemoan students' lack of writing and thinking skills, students have mostly demonstrated a remarkable skill at gaming the system and, for the most part, getting away with it.

I am not questioning the necessity of teaching students critical thinking and rhetorical skills; I am simply saying that we should be teaching writing without writing. What I mean by writing is this: The thesis-based five paragraph essay and the research-based long form academic essay are no longer useful, both because of changes in the nature of information consumption and the ability of students to purchase custom-written essays online. Writing programs should be focused on the types of writing that students will actually do once they leave the University for the Work World, writing that focuses on the technical and work- related skills they will actually use on the job. Because of the fundamental paradigm shift in the nature of how information is digested, the ability to convey information in short, direct bursts of writing has replaced the ability to write long, complex sentences and fully developed paragraphs. There is little need any longer to train undergraduate students as mini versions of college professors.

In truth, many writing classes have little to do with teaching writing and rhetorical skills, and much to do with riding political hobbyhorses or other professorial obsessions. I have sat through writing courses where professors have pimped for universal health care, railed against Republicans, pleaded for social justice, promoted electric cars and carbon credits, preached for gay marriage, and pushed other social and political talking points, all at the expense of teaching writing, critical thinking, or rhetorical skills. Having students parrot a professor's political views or current research hobbyhorse is not teaching writing, and in many cases isn't teaching critical thinking or rhetorical skills, but a seeking out of confirmation bias. As Richard Arum and Josipa Roksa show in Academically Adrift, 45 percent of college seniors demonstrated no significant gains and 36 percent showed no improvement at all in critical thinking and writing skills. The part-time adjunct/teaching assistant system of general education, while financial profitable, has been a miserably failure academically. If universities were corporations tallying numbers like these, they would have been out of business by now.

And yet the rhet/comp juggernaut continues to be the bread and butter not only of English departments but general education programs as well. If the teaching of writing is the most important job on campus, simply remove it as a Gen Ed requirement for accreditation and see how long it takes for English departments to shutter the shop.Another point: if teaching critical thinking skills $i s$ the most important job on campus, then it should be delegated to those most qualified to teach critical thinking skills: not TA's, adjuncts, and those few left scurrying on the tenure track but tenured professors who have been trained in the art of rhetoric and argumentation; not trained in literary studies, MA TESOL, education, composition, cultural studies, feminist theory, or even linguistics. Our former dean once said, "anyone can teach writing," and while that's demonstrably not true, it is true that on many campuses anyone available and breathing for the semester can be hired to teach writing. In conversation, I am often amazed by the lack of fundamental knowledge of argumentation that many writing teachers demonstrate. I'm also amazed by the lack of knowledge about argumentation that some composition textbooks demonstrate as well. At the start my advanced academic writing class this semester, I asked my 24 students how many of them had learned the difference between inductive and deductive reasoning in their previous academic writing classes: two raised hands, both former students of mine. Arum and Roksa would not be surprised. 
The traditional model of liberal education served the needs of a leisure-based class; the $21^{\text {st }}$ century information revolution has rendered these needs obsolete. Writing programs should be focused on the types of writing that students will actually do once they leave the University for the Work World, writing that focuses on technical and work-related skills they will actually use on the job. The ability to convey information in short, clear, direct bursts of writing is now the standard model of communication, not the ability to write long, complex sentences in fully developed paragraphs, page after page after page. We may lament the demise of the academic essay, but unless we move beyond it, we'll be lamenting the demise of our jobs.

Instead of teaching students how to parrot professorial biases in 4-6 pages of academic prose, we should be teaching them the information forms of the $21^{\text {st }}$ century. In addition, we should also still be teaching them the basics of argumentation and rhetorical strategies, which are the foundation of a firm base of critical thinking skills. Just because the writing demands have changed doesn't mean the critical thinking skills behind them have. Critical thinking skills are more important than ever, if only to empower students to be better "consumers" of their own education, as well as better citizens able to critically assess the increasingly shrill and hysterical political and media environments around them. The rules of rhetoric and argumentation remain unchanged.

The Internet has made writing traditional academic essays as irrelevant as CDs, DVDs, and traditional library research. Students can not only find the information they need online or via library databases, they can also find those willing to turn that information into passable essays for just about any type of assignment. "Writing" these essays does not teach students how to use critical thinking or rhetorical skills, and evaluating bought essays certainly doesn't lead to our supplying accurate outcomes assessment of student ability; these assignments are merely hurdles students need to clear in order to leave the world of general education behind and move onto their major certificate track.

It's ironic that as first year graduate students, stumbling our way through our first teaching assignment, we were also required to take a yearlong seminar in classical rhetoric. The following year our required textbooks for first year composition were Aristotle's Rhetoric and Edward P.J. Corbett's Classical Rhetoric for the Modern Student. I can't tell you how these requirements affected our students, but these requirements certainly had a long term affect not only on myself but on my career as well. Why not leave our current students with actual skills they can use, long after spending a couple of required semesters among those of us still doing most important job on campus? According to Justin Stover, "Academic works are written for many reasons - for qualification, for institutional and personal advancement, even to be a lasting contribution. But they are not written to be read, at least in the normal sense of the term." Let's make them write content worth reading.

\section{References}

Arum, R., \&Roksa, J. (2011). Academically adrift. Chicago: The University of Chicago Press

Freese, J. H: Aristotle: The Art of Rhetoric (1967). Cambridge, MA: Harvard University Press

Stover, J. "There is No Case for the Humanities." The Chronicle of Higher Education, March 4, 2018

Taleb, N. N. (2018) Skin in the game: Hidden asymmetries in daily life. New York, NY: Random House 